\title{
Miksi julkisisssa ruokapalveluissa on niin vaikea käyttää ekologisia raaka- aineita?
}

\author{
Minna Mikkola \\ Helsingin yliopisto, Ruralia-instituutti, Lönnrotinkatu 7, 50100 Mikkeli, minna.mikkola@nic.fi
}

\section{Tiivistelmä}

Kestävät ruokapalvelut on käsite, jonka ajatuksena on edistää kestävää tuotantoa ja kulutusta. Kestävissä ruokapalveluissa pyritään käyttämään lähi- ja luomuruokaa ja jopa lähiluomuruokaa, jotka ymmärretään yleensä ekologisiksi vaihtoehdoiksi. Käytännössä toiminnassa on kuitenkin ongelmia. Tämän tutkimuksen tarkoitus on syventyä julkisiin ruokapalveluihin ekologisen ruoan käyttäjinä: miksi julkisisssa ruokapalveluissa on niin vaikea käyttää ekologista ruokaa? Tässä artikkelissa käytetään lyhyyden vuoksi termiä ekologinen ruoka ympäristöystävällisen ruoan sijasta.

Tutkimuksessa kysytään, miten ammattilaiset ruokapalveluorganisaatioiden eri tasoilla ymmärtävät ekologisen ruoan, millaisia jännitteitä sen käytössä syntyy eri tasojen välille ja miten ekologisen ruoan käyttöä voitaisiin edistää. Tutkimuksen aineistona on 15 kunnallisen ruokapalveluammattilaisen haastattelut vuosina 2000-2003. Tutkimus tukeutuu Goffmanin (1959) ja Argyriksen (1999) organisaatioissa ilmenevää käyttäytymistä sekä Bakhtinin (1982) 'ammatillista puhetta’ koskeviin käsitteisiin.

Tulokset osoittavat, että ammattilaiset eivät puhuneet 'ekologisesta ruoasta', mutta sitä kuitenkin lähestyttiin jo käytössä olevien käsitteiden ja toiminnan tavoitteiden kautta. Ekologia ja ympäristö liittyivät kiinteimmin ympäristöterveyteen, ruoan mahdollisiin muihin oletettuihin myönteisiin terveysvaikutuksiin, ympäristöteknisiin piirteisiin kuten energian ja veden kulutukseen ja vasta viime kädessä ympäristön tilaan sinänsä. Ympäristöuhkina nähtiin rehevöityminen, maaperän saastuminen ja polttoaineiden kuluminen. Sen sijaan esimerkiksi biodiversiteetti ja ilmastonmuutos olivat käsitteitä, joita ei puhuttu lainkaan; 'ympäristö' oli käsitteellisesti monimutkaisesti välittynyt ja kaukana 'keittiöstä'.

Ruoan ekologisia piirteitä lähestyttiin käytännöllisen ryhmittelyn avulla. Ammattilaiset puhuivat kotimaisesta, ulkomaisesta, lähi- ja luomuruoasta sekä 'ympäristöteknisestä' ruoasta. Ryhmittely ei kuitenkaan tuottanut ongelmattomasti käytännön ohjenuoraksi soveltuvia kategorioita, vaan pikemminkin nosti vastakkainasetteluita joissa tietty ryhmä näkyi sekä hyvänä että kyseenalaistettuna ruokana. Lisäksi ympäristötekninen ruoka nähtiin hyvin vaikeasti täsmennettävänä mutta todellisena ilmiönä. Tulokset kertovat ammattilaisten käyttämästä ryhmittelystä, sen mahdollisesta horjuvuudesta, tiedon tarpeesta ja näkemyseroista organisaatioiden eri tasojen välillä.

Ilmeisesti ekologinen ruoka tarvitsee huomattavasti perusteiden selkiyttämistä ja käsitteellistä kirkastamista jotta kriittiset ammattilaiset voivat uudistaa näkemyksensä siitä mitä ekologinen ruoka on ja hyödyntää tätä tietoa toiminnassaan. Tulevaisuuden kestävien ruokapalveluiden rakentamisessa tarvitaan organisaatioiden eri tasojen ammattilaisten ja asiantuntijoiden yhteistyötä.

\section{Asiasanat}

Julkiset ruokapalvelut, kestävät ruokapalvelut, ekologinen ruoka, kotimainen ruoka, ulkomainen ruoka, lähiruoka, luomuruoka, ympäristötekninen ruoka

\section{Johdanto}

Kodin ulkopuolella syötyjen ruoka-annosten määrä kasvaa Suomessa jatkuvasti n. kaksi prosenttia vuodessa. Vuonna 2007 kahvilat, ravintolat ja julkiset keittiöt tarjosivat lähes 800 miljoonaa ateriaa, ja keskimäärin puolet suomalaista käyttää päivittäin joitakin ruokailupalveluita kun ateriapalveluita käyttää noin kolmannes. Suomessa toimii yli 17000 valmistuskeittiötä, joista n. 5000 on julkisia (ACNielsen 2007). Näiden lukujen perusteella ruokapalveluala on keskeinen elintarvikkeiden hankkija joka vaikuttaa väestön ravitsemukseen ja hyvinvointiin parantaen arkipäivän työssä jaksamista. Viime 
aikoina on kuitenkin tunnistettu että julkisilla ruokapalveluilla on myös mahdollisuuksia parantaa ympäristön tilaa ja edistää kestävää kehitystä omassa toiminnassaan.

Uutta suuntausta konkretisoi kestävien ruokapalveluiden käsite (Morgan ja Sonnino 2005), jota toteutetaan julkisissa ruokapalveluissa mm. Englannissa, Italiassa, Ruotsissa ja Tanskassa, (Sonnino 2007, Löfven 2006, Cristensen 2006). Näissä julkisissa ruokapalveluissa käytetään mahdollisuuksien mukaan sekä lähi- ja luomuruokaa että lähiluomuruokaa, joiden oletetaan edustavan ympäristömyötäisyyttä ja kestävää kehitystä. Kestävät ruokapalvelut pyrkivät kasvattamaan ympäristöystävällisen ruoan kysyntää ja edistämään kestävää maataloutta ja luonnonmukaista tuotantoa (EEC 1991, European Commission 1999, 2005). Kestävän kulutuksen ja tuotannon ohjelmassa (KULTU 2005) esitetään että luomuviljelyn pinta-ala nousee vuoteen 2010 mennessä 10 \% peltopinta-alasta ja vuoteen 2025 mennessä 25 \% siitä. Lisäksi esitetään että ammattikeittiöt - sekä julkiset että kaupalliset - lisäävät luomu- ja lähiruoan käyttöä 10-15 \% vuosittain. Ammattikeittiöiden ekologista toimintaa on myös arvioitu Suomessa (Taskinen ja Tuikkanen 2004). Kestävistä ruokapalveluista tiedotetaan ympäristömerkinnällä (Swan labelling of restaurants 2006), jonka tavoitteena on lisätä alan näkyvyyttä ja liikevaihtoa.

Toistaiseksi ei voitane sanoa, että kestävät ruokapalvelut edustaisivat Suomessa alan valtavirtaa. Suomessa n. 5000 julkisesta valmistuskeittiöstä vain n. 200 käyttää vähintään kahta luomuraaka-ainetta päivittäin (Luomukeskus 2007) ja lähes 22000 ammattikeittiöstä vain n. 1500 keittiön arvioidaan käyttävän jossain määrin päivittäin luomuraaka-aineita (Finfood Luomu 2007). Kuitenkin lähiruokaa käytetään julkisissa ruokapalveluissa ilmeisesti melko laajasti (Paananen ja Forsman-Hugg 2005). Ilmeisesti julkisten ruokapalveluiden käytännöt ja poliittiset tavoitteet eivät vielä kohtaa ja voidaan päätellä, että ekologisten raaka-aineiden käyttö ei ole ongelmatonta. Tässä tutkimuksessa kysytään miksi julkisissa ruokapalveluissa on niin vaikea käyttää ekologisia raakaaineita ja etsitään erityisesti vastausta siihen, miten ekologiset raaka-aineet ymmärretään ruokapalveluorganisaatioiden eri tasoilla. Tulokset auttavat tunnistamaan nykyisen tilanteen ongelmia ja ratkaisemaan niitä kestävien ruokapalveluiden edistämiseksi.

\section{Aineisto ja menetelmät}

Ruokapalveluorganisaatioden ammattilaiset toimivat erilaisissa tehtävissä ja niiden mukaisissa asemissa. Goffmanin (1959) jaottelua näyttämön etu- ja takaosan toimijoista on hyödynnetty tutkimuksessa niin, että on huomioitu etuosan toimijat, keittiöiden esimiehet, keskialueen toimijat, ruokapalvelupäälliköt, ja takaosan toimijat eli julkiset hankkijat. Ammattilaiset kehittävät ekologisen ruoan käyttöä ruokapalveluorganisaatioissa sovittamalla yhteen tehtäviään ja asemiaan (Kärkkäinen 1999).

Tutkimuksen aineistona on 15 kunnallisen ruokapalveluammattilaisen haastattelut vuosina 20002003. Ne toteutettiin sekä pääkaupunkiseudun että maaseudun kunnissa niin, että haastateltavat edustivat sekä julkisia hankkijoita (3), ruokapalvelupäälliköitä (8) ja keittiöiden esimiehiä (4). Haastattelut olivat avoimia teemahaastatteluita, joissa haastateltavia pyydettiin kertomaan omasta toiminnastaan ja miten he ymmärsivät elintarvikkeiden ja ympäristön välillä vallitsevia yhteyksiä. Haastattelut nauhoitettiin ja litteroitiin sanatarkasti.

Aineisto analysoitiin niin että tekstimassasta etsittiin ne kohdat, joissa haastateltavat puhuivat elintarvikkeista ja niiden ympäristöön liittyvistä ominaisuuksista. Puhe sisälsi käsityksiä, jotka kuuluivat sekä maatalous-, elintarvike- ja ympäristötieteelliseen että ammatilliseen viitekehykseen. Nämä tekstikohdat koottiin ammattilaisten kolmen tehtävän ja aseman mukaan yhteen ja niitä tarkasteltiin Bakhtinin (1982) mukaan toimijoiden ammatillisena puheena, joka on alalle yhteistä, konkreettista, pohtivaa ja arvottavaa. Toimijoilla on ammatillinen käsitehorisontti, johon uusien käsitteiden kuten ympäristö tai ekologia on sijoituttava niin että toimijat voivat suhteuttaa ja yhdistää uudet käsitteet ja käytännöt vanhoihin. Toimijoiden ammatillinen muutos käynnistyy käsitehorisontin rakentamisesta uudelleen niin että ympäristö ja ekologisuus kuuluvat ymmärrettävinä osina uuteen kokonaisuuteen. Argyris $(1957,1999)$ kuvaa organisaation sisäisiä ristiriitoja ja niiden mahdollista ratkaisua organisaation tehtävän uudelleen muotoilun avulla. 


\section{Tulokset}

Toimijoiden ammatillinen puhe koski tiettyjä tuotteita, ympäristöterveyttä ja tuotelaatua, tuotteen terveysvaikutuksia, tuotantomenetelmiä, tuotteen alkuperää tuotantopaikkana ja tuotantoympäristön tilaa sekä eläinten hyvinvointia. Lisäksi haastateltavat puhuivat ruoan ympäristöteknisestä laadusta. Näitä seikkoja käsiteltiin henkilökohtaisina havaintoina ja muistinvaraisena informaationa joita pohdittiin kriittisesti ja joiden perusteella arvotettiin ruoan ekologisuutta. Tässä tutkimuksessa esitetty analyyttinen ryhmittely vastaa haastateltavien käyttämää ryhmittelyä jonka avulla esitettiin puhetta hyvästä ruoasta sekä vastapuhetta kyseenalaistetusta ruoasta. Ruoan ympäristöteknisestä laadusta puhuttiin lähinnä käytännön toiminnan ja tutkimuksen kohteena.

\section{Hyvä kotimainen ruoka}

Kotimainen ruoka oli niin 'tavallista' että siitä tuskin edes puhuttiin tavanomaisena erotuksena luomuruoasta. Kotimaista ruokaa pidettiin turvallisena puhtautensa takia; siinä ei esiinny haitallisia mikrobeja, hullun lehmän tautia, ei jäämiä antibiooteista tai hormoneista. Kotimaiset marjat eivät sisältäneet torjunta-aineita tai kalikiviruksia. Ammattilaiset muistelivat eri elintarvikkeita koskevia aiempia tiedonantoja, jotka käsittelivät tuotteiden puhtautta. Toisaalta kuitenkin ymmärrettiin keinolannoitteiden ja torjunta-aineiden käyttö tuotannossa eräänlaisina välttämättömyyksinä, jotka tosin johtivat toisinaan alhaisiin jäämäpitoisuuksiin. Ammattilaiset kuitenkin katsoivat, että ilman näitä kemikaaleja satotasot voisivat laskea, mikä uhkaisi lopulta kotimaista ruokaturvaa ja ruoan turvallisuutta.

Lisäksi ammattilaiset luottivat erilaisiin viranomaistarkastuksiin ja analyyseihin. Luottamus ei kuitenkaan pohjautunut kritiikittömyyteen, vaan monet haastateltavat muistelivat kotimaisia EHECtapauksia ja räikeitä eläinten hyvinvointiongelmia; näitä pidettiin kuitenkin lähinnä poikkeuksina vallitsevasta hyvästä tilanteesta.

Myönteisiä arvioita kotimaisen ruoan turvallisuudesta perusteltiin yleisesti ympäristön puhtaudella ja erityisesti tuotantoympäristön puhtaudella. Lisäksi kotimaisen ruoan käyttöön liitettiin maaseudun kehittyminen ja työllisyyden ylläpitäminen. Erityisesti hankkijat korostivat yhteistyötä kotimaisen teollisuuden kanssa joka takasi ruokaketjun toimivuuden. Julkisissa ruokapalveluissa käytettiin runsaasti kotimaista ruokaa johon asiakkaat olivat yleensä tyytyväisiä.

\section{Kyseenalaistettu kotimainen ruoka}

Huolimatta kotimaisen ruoan yleisestä arvostuksesta haastateltavat kaikilla organisaatiotasoilla myös kyseenalaistivat sen. Ammattilaiset näkivät että loppujen lopuksi heillä oli niukat tiedot alkutuotannosta ja prosessoinnista, ja päättelivät, että myös Suomesta löytyy 'tehotuotantoa' myrkkyineen ja päästöineen. Monet haastateltavat osoittivat 'jäämäahdistusta' ja katsoivat, että varsinainen kysymys, johon he halusivat vastausta, oli tavanomaisen ruoan puhtaus verrattuna luomuruokaan.

\section{Hyvä ulkomainen ruoka}

Erityisesti hankkijat katsoivat että ulkomainen ruoka voi olla jopa parempi vaihtoehto kuin kotimainen, edellyttäen että tiedossa ei ole negatiivisia seikkoja kuten hullun lehmän tautia. Hankkijat totesivat ettei heillä ollut mitään mielikuvaa ulkomaisista tuotanto-olosuhteista ja että virallisiin tarkastuksiin täytyi voida luottaa. Ulkomaista lihaa ja marjoja käytettiin jonkun verran sekä kaupunkien että maaseudun julkisissa ruokapalveluissa.

\section{Kyseenalaistettu ulkomainen ruoka}

Useimmat keittiöiden esimiehet ja ruokapalvelupäälliköt suhtautuivat ulkomaiseen ruokaan kielteisesti. Tuontimarjoissa oli ollut kalikiviruksia ja iduissa salmonellaa, jotka olivat aiheuttaneet epidemioita. Paprikoissa oli todettu korkeita jäämäpitoisuuksia ja omenat eivät 'koskaan pilaantuneet'. 'Etelässä' ei pidetty yhtä tiukasti kiinni säädöksistä ja määräyksistä kuin 'Pohjoisessa'; eläinkuljetukset herättivät huolta eläinten huonosta kohtelusta. Hullun lehmän tauti ei aiheuttanut juurikaan kotimaisen naudanlihan käytön vähenemistä mutta nosti esiin lihajärjestelmässä vallitsevan ahneuden ja moraalittomuuden etenkin ulkomailla. Lisäksi ulkomaiseen ruokaan liitettiin kuljetusten päästöt ja ympäristön saastuminen; hankkijat suhtautuvat näihin ongelmiin neutraalisti. 


\section{Hyvä lähiruoka}

Keittiöiden esimiesten ja ruokapalvelupäälliköiden näkökulmasta lähiruoka oli tuotettu 50-100 km säteellä tai yhteisellä sosio-ekonomisella alueella kuten esim. sairaanhoitopiirin kuntien alueella. Lähiruokaa ei tuotettu massamittakaavassa, siinä ei ollut 'paljoa myrkkyjä', eikä se aiheuttanut kuljetustarpeita 'maan ääriin'. Lähiruoan toimittajat mahdollistivat myös yhteistyön tuotelaadun kehittämiseksi. Lähiruoka paransi työllisyyttä, mahdollisti tuoreen ja 'autenttisen' ruoan sekä uudelleen käytettävien pakkausten käytön. Lähiruokaa käytettiin erityisesti maaseudulla, jossa oltiin tietoisia myös lähiruoan myönteisestä imagosta. Suurten kaupunkien hankkijat eivät kuitenkaan puhuneet lähiruoasta.

\section{Kyseenalaistettu lähiruoka}

Vaikka lähiruokaa arvostettiin, jotkut ammattilaiset totesivat että lopultakin he tiesivät hyvin vähän lähiruoan todellisesta laadusta, paikallisesta alkutuotannosta tai jalostuksesta. Lukuunottamatta henkilökohtaisia havaintoja paikallisen ympäristön tila tunnettiin heikosti, mikä herätti ammattilaisissa epävarmuutta.

\section{Hyvä luomuruoka}

Kaikki ammattilaiset olivat tietoisia että luomuruoka tuotettiin ilman keinolannotteita ja torjuntaaineita. Luomuruokaa pidettiin hyvin puhtaana, sen katsottiin olevan vailla 'vaarallisia aineita' ja suojaavan maaperää saastumiselta. Jotkut ammattilaiset kertoivat tunnistavansa luomutuotteiden hyvän maun ja esittivät tuotteiden myös säilyvän hyvin. Osa myös oletti luomutuotteiden olevan ravitsevampia ja eettisesti korkeatasoisempia kuin tavanomaisten tuotteiden. Joitakin luomutuotteita käytettiin etenkin maaseudun ammattikeittiöissä mutta niistä ei useinkaan tiedotettu asiakkaille. Luomupäivät tai -viikot järjestettiin erikseen ja niistä myös tiedotettiin.

\section{Kyseenalaistettu luomuruoka}

Jotkut ruokapalvelupäälliköt muistelivat että luomuruoasta puuttui seleeniä ja toisinaan siinä saattoi olla ylimäärin nitraattia. Luomulannoitteiden arveltiin tuovan mahdollisesti jopa tauteja aiheuttavia mikrobeja ruokaketjuun. Ruokapalvelupäälliköt katsoivat että luomutuotannossa sato voi kärsiä ilmaston vaihteluista, tuholaisista ja taudeista. Luomuun siirtymistä pidettiin pitkänä sukupolviprosessina, josta parhaiten vastaisi maatalous ja elintarviketeollisuus, jotka olivat vastuussa miljoonien ihmisten ruokkimisesta. Yhäkkinen siirtyminen luomuun merkitsisi tähänastisten saavutusten kyseenalaistamista. Lisäksi keittiöiden esimiehet ja ruokapalvelupäälliköt pitivät hankalana luomuruoan osittaista käyttöä, minkä vuoksi keittiön tulisi siirtyä kokonaisuudessaan luomuun. Monet eivät myöskään nähneet mitä lisäarvoa luomu heille antaisi ja mitä merkitystä sillä olisi asiakkaalle. Lopulta osa katsoi ettei luomutuoteissa ollut erityistä makua ja niitä markkinoitiin erilaisilla väittämillä, jotka tekivät luomuruoan käytön perusteista entistä sekavampia.

\section{Ympäristötekninen ruoka}

Keittiöiden esimiehet ja ruokapalvelupäälliköt pohtivat energian ja veden kulutusta keittiössä aterioiden valmistuksessa. Työnjako teollisuuden ja keittiöiden välillä nähtiin ympäristökysymyksenä, johon liittyi myös henkilökunnan työmäärä. Keittiöissä katsottiin kuitenkin että elinkaarianalyysit ja muut vastaavat menetelmät olivat aivan liian vaikeita ja työn sisällön vuoksi ammattilaisten ulottumattomissa. Ympäristö näyttäytyi etäisenä, joskin joitakin mainintoja rehevöitymisestä ja saastumisesta esitettiin. Ammattilaiset olivat hyvin tietoisia kuljetuksista ja niitä pyrittiin vähentämään hankkimalla kaikki tuotteet samalta toimittajalta. Pakkausjätteen määrää haluttiin vähentää ja tavoite oli jossain määrin saavutettu teollisuusyhteistyön avulla. Keittiöiden esimiehet vähensivät ruokajätteen määrää huomioimalla aiempaa paremmin ruokailijoiden määrän ja järjestämällä itseannostelun; 'ota minkä syöt.'

Hankkijat olivat kehittäneet ekologiselle ruoalle hankintamatriiseja yhteistyössä ympäristöasiantuntijoiden kanssa, mutta ruokaa oli arvioitu lähinnä pakkausten ja kuljetusten kannalta. Hankkijat ja ruokapalvelupäälliköt näkivät että ekologiselle ruoalle tarvittaisiin ympäristökriteerejä, mutta jo näiden kriteerien perusteista päättäminen nähtiin vaikeaksi. Lopulta kriteerejä tulisi myös voida soveltaa käytännön työssä. 'Ympäristötekninen' ruoka osoittautui vaikeasti määriteltäväksi ja siten ongelmalliseksi hankittavaksi, mutta ammattilaiset katsoivat että kehitystyötä on kuitenkin jatkettava. 


\section{Tulosten tarkastelu}

Ekologinen ruoka oli käsite josta ammattilaiset eivät sellaisenaan puhuneet. Käsite kuvaa kuitenkin hyvin sitä mihin ammattilaiset pyrkivät kaikkien muiden tavoitteiden ohella. Ekologinen ruoka oli intentionaalinen, 'kätketty' käsite jota ei lähestytty sellaisenaan vaan muiden käsitteiden kautta, niiden ominaisuuksia huomioiden ja niihin sovittautuen. Ekologinen ruoka oli myös laaja ja jännitteinen käsite, jossa usein korostettu kotimaisen ruoan arvostus oli näkyvissä mutta myös sen kyseenalaistaminen tuli esiin. Vastaavasti myös lähi- ja luomuruokaa sekä arvostettiin että myös kyseenalaistettiin, samoin kuin ulkomaista ruokaa. Ekologinen ruoka oli myös erityinen käsite, jolloin elintarvikkeita käsiteltiin sekä 'tiettynä tuotteena' että omana tuoteryhmänään. Ammattilaiset olivat kriittisiä ja käyttivät pitkän ajan kuluessa kertynyttä tietoa muodostaakseen käsityksiä ruoan ekologisesta laadusta. Näistä käsityksistä myös keskusteltiin laajasti jokapäiväisessä työssä jolloin niistä tuli yhteisesti jaettuja. Lisäksi ammattilaisten tehtävä ja asema vaikutti heidän näkemyksiinsä niin että mitä lähempänä ruoanvalmistusprosessia toimittiin, sen tärkeämmäksi tulivat kotimainen ja lähiruoka; mitä kauempana prosessista työskenneltiin, sen myönteisemmältä myös ulkomainen ruoka vaikutti. Lisäksi ruoanvalmistusprosessiin osallistuvat ammattilaiset - keittiöiden esimiehet ja ruokapalvelupäälliköt - korostivat prosessin optimointia teollisuuden kanssa, kun sen sijaan hankkijat kehittivät laajoja ja yleisiä ympäristökriteerejä.

\section{Johtopäätökset}

Ekologista ruokaa on vaikea käyttää ruokapalveluorganisaatioissa koska käsitteen sisältöä ei tunneta riittävästi eikä tiedetä, miten eri elintarvikkeet vastaavat tavoiteltuun ekologisuuteen. Ekologinen ruoka oli ruokapalvelualan ammattilaisille tavoitteinen, jännitteinen ja 'epäitsenäinen' käsite, jota voitiin toteuttaa vain ruoan muiden tavoiteltujen ominaisuuksien yhteydessä. On erityisesti huomioitava että vaikka kotimaisella ruoalla on vankka asema, sitä myös kyseenalaistetaan; samoin lähi- ja luomuruoka eivät näyttäydy vain yksiselitteisen myönteisinä, vaan niissä nähdään myös puutteita. Näiden tulosten perusteella toistaiseksi esitetty väite suomalaisen ruoan puhtaudesta lienee ammattilaisille tuttu ja pääosin siihen luotetaan, mutta kyseenalaistaminen kertoo lisätiedon tarpeesta. Väite puhtaudesta tarvitsee tuekseen asiallista sisältöä, joka mahdollistaa tuote- ja tuoteryhmätasolla eronteon kotimaisen, ulkomaisen, lähi- ja luomuruoan välillä. Lisäksi ammattilaiset tarvitsevat yhteistyötä tutkimuksen kanssa jotta ruoan ympäristöteknisestä laadusta voitaisiin päästä ympäristökriteereihin ja niiden käyttöön. Ekologinen ruoka ymmärrettiin ruokapalveluorganisaatioissa myös eri tavoin tehtävästä ja asemasta riippuen.

Jos julkisissa ruokapalveluissa halutaan lisätä ekologisen ruoan käyttöä, on ammattilaisten kysymyksiin voitava vastata. Mitä eroja on kotimaisen, lähi- ja luomuruoan ja ulkomaisen ruoan eri tuotteiden välillä erityisesti puhtaudessa ja ympäristöteknisissä näkökohdissa? Työssä tarvitaan ruokapalveluorganisaatioiden eri tehtävissä toimivien ammattilaisten ja elintarvike- ja ympäristöasiantuntijoiden tutkimusyhteistyötä, joka myös kehittäisi organisaatioissa ammattilaisten yhteistä näkemystä ekologisesta ruoasta. Kestävien ruokapalveluiden ja ekologisen ruoan käytön kehitäminen näyttäytyy laajana tutkimus-, opetus- ja kehitystehtävänä, joka mahdollistaa myös ruokapalveluorganisaatioille niiden tehtävän uudelleenmäärittelyn kestävän kehityksen edistäjinä.

\section{Kirjallisuus}

ACNielsen 2007. Kodin ulkopuolella syötyjen annosten määrä kasvoi. Tiedote. Horeca-rekisteri 2007. Saatavilla 06.12.2007 osoitteessa http://www.acnielsen.fi/site/index.shtml

Argyris, C. 1957. Personality and Organisation. The Conflict between System and the Individual. Harper Torchbooks, Harper \& Row, New York, Evanston and London, 291 pp.

Argyris, C. 1999. On Organizational Learning. Oxford, UK: Blackwell Publishers Ltd.

Bakhtin, M.M. 1982. Discourse in the Novel. In: M.M.Bakhtin, The Dialogic Imagination. Four Essays. University of Texas Press, Austin, pp. 259-422. 
Christensen, T. A. 2006. An organic locomotive. Dogme Project on Organic Food - in the City of Copenhagen. Paper presented at the Conference on Healthy and Sustainable Public Food Network in Norden, Copenhagen. Saatavilla 2006-06-20 osoitteessa http://www.healthcat.net

European Commission 1999. 27.01.1999. Directions towards sustainable agriculture. Saatavilla 10.10.2007 osoitteessa http://ec.europa.eu/agriculture/envir/9922/9922_en.pdf

European Commission 2005. Agri-environment Measures - Overview on General Principles, Types and Measures, and Application. Saatavilla 10.10.2007 osoitteessa http://ec.europa.eu/agriculture/publi/reports/agrienv/rep_en.pdf

EEC 1991. Concil Regulation No 2092/91 of 24 June 1991 on organic production of agricultural products and indications referring thereto on agricultural products and foodstuffs.

Finfood Luomu 2007. Ammattikeittiöille. Saatavilla $\quad$ A $\quad$ osoitteessa http://www.finfood.fi/finfood/luomu.nsf/0/FE535462B537B698C225707D0040AB49?opendocument\&cat1=Pal velut\&cat2=Ammattikeitti\%F6ille

Goffman, E. 1959. The presentation of self in everyday life. Doubleday, New York, 251 pp.

KULTU 2005. Vähemmästä enemmän ja paremmin - Kestävä kulutuksen ja tuotannon toimikunnan (KULTU)

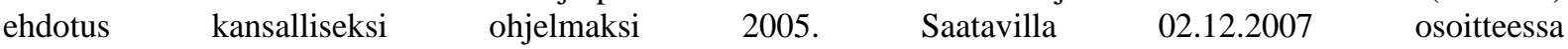
http://www.ymparisto.fi/default.asp?node=7468\&lan=fi

Kärkkäinen, M. 1999. Teams as breakers of traditional work practices (Academic disseration). Department of Education, University of Helsinki. Research Bulletin 100. Helsinki.

Luomukeskus 2007. Portaat luomuun -keittiöt. $\quad$ Saatavilla 10.10 .2007 osoitteessa http://www.luomukeskus.net

Löfven, H. 2006. Public food and climat - the Malmoe school meal case. Paper presented at the Conference on Healthy and Sustainable Public Food Network in Norden, Copenhagen. Saatavilla 20.6.2007 osoitteessa http://www.healthcat.net

Morgan, K., \& Sonnino, R. 2005. Catering for Sustainability. The Creative Procurement of School Meals in Italy and the UK: ISBN 1-902647-49-1.

Paananen, J., \& Forsman-Hugg, S. 2005. Lähi- ja luomuruoka kunnallisissa ruokapalveluissa. Esiselvitys päättäjien näkemyksistä. MTT:n selvityksiä 88. Maa- ja elintarviketalouden tutkimuskeskus.

Sonnino, R. 2007. Quality Food and Sustainable Development: The Power of the Public Sector. Saatavissa 06.12.2007 osoitteessa http://mmm.multiedition.fi/laatunen/uutiskirje/laatuset/10_2007/uutinen_esitykset.php

Swan labelling of restaurants 2006. Version 1.0. 13. December 2006 - 31 December 2009. Saatavilla 10.10.2007 osoitteessa http://www.svanen.nu/Eng/criteria/kriterie.asp?pgn=91

Taskinen, T., \& Tuikkanen, R. 2004. Ammattikeittiöiden ekologinen toiminta Suomessa 2003. Mikkelin ammattikorkeakoulu, Mikkeli. 